\title{
Control of progesterone production in small and large bovine luteal cells separated by flow cytometry
}

\author{
H. W. Alila*, J. P. Dowd*, R. A. Corradino*, W. V. Harris $\dagger$, \\ and W. Hansel* \\ Departments of *Physiology, and $\uparrow$ Microbiology, Baker Institute of Animal Health, New York \\ State College of Veterinary Medicine, Cornell University, Ithaca, NY 14853, U.S.A.
}

\begin{abstract}
Summary. Corpora lutea were collected from Holstein heifers on Days 10 and 12 of the oestrous cycle and the cells were dispersed with collagenase. The dispersed cells were separated into preparations of highly purified (90-99\%) small $(<20 \mu \mathrm{m})$ and large $(>25 \mu \mathrm{m})$ luteal cells by unit gravity sedimentation and fluorescence-activated cell sorting. Net progesterone accumulation by $1 \times 10^{5}$ small cells and $1 \times 10^{3}$ large cells during 2 and $4 \mathrm{~h}$ incubations, respectively, were measured after additions of LH, PGF$2 \alpha$, and phorbol esters, alone and in combination. Progesterone synthesis was increased $(P<0.05)$ by phorbol dibutyrate $\left(\mathrm{PBt}_{2}\right)$ or PGF- $2 \alpha(P<0.05)$ in small, but not in large, luteal cells $\left(10 \cdot 1 \pm 3 \cdot 0\right.$ and $18 \cdot 1 \pm 5 \cdot 0 \mathrm{ng} / 10^{5}$ cells for 0 and $50 \mathrm{nM}-\mathrm{PBt}_{2}$, and $19 \cdot 9 \pm 3 \cdot 2$ and $44 \cdot 2 \pm 9 \cdot 3 \mathrm{ng} / 10^{5}$ cells for 0 and $1 \mu \mathrm{g}$ PGF $\left.-2 \alpha / \mathrm{ml}\right)$. The previously reported stimulatory effects of PKC activation and PGF- $2 \alpha$ addition to total dispersed cell preparations are therefore entirely attributable to the small, theca-derived cells. Small cells responded to low levels of $\mathrm{LH}(9 \cdot 1 \pm 1 \cdot 1,69 \cdot 0 \pm 5.4$ and $154.7 \pm 41 \cdot 4 \mathrm{ng} /$ $10^{5}$ cells for 0,1 and $5 \mathrm{ng} \mathrm{LH} / \mathrm{ml}$, respectively, $P<0.05$ ), while large cells responded only to high levels of $\mathrm{LH}\left(1635 \pm 318,2662 \pm 459\right.$ and $3386 \pm 335 \mathrm{pg} / 10^{3}$ cells for 0 , 100 and $1000 \mathrm{ng} \mathrm{LH} / \mathrm{ml}$, respectively, $P<0.05$ ). PGF-2 $\alpha$ inhibited LH-, 8-Br-cAMPand forskolin-stimulated progesterone synthesis in the large cells (3052 \pm 380 , $3498 \pm 418,3202 \pm 391 \mathrm{pg} / 10^{3}$ cells for $1 \mu \mathrm{g} \mathrm{LH} / \mathrm{ml}$, and $0.5 \mathrm{mM}-8-\mathrm{Br}-\mathrm{cAMP}$, and $1 \mu \mathrm{M}$-forskolin respectively and $1750 \pm 487,2255 \pm 468,2165 \pm 442 \mathrm{pg} / 10^{3}$ cells for PGF- $2 \alpha+$ LH, PGF- $2 \alpha+8$-Br-cAMP and PGF- $2 \alpha+$ forskolin, respectively), indicating that the inhibitory effect of PGF- $2 \alpha$ on progesterone synthesis in large cells occurs at a site distal to cAMP generation. These results suggest that the large cells are the targets of the luteolytic effects of PGF-2 $\alpha$, while the small cells are responsible for the previously reported luteotrophic effect of PGF-2 $\alpha$ in vitro.
\end{abstract}

Keywords: corpus luteum; cell sorter; prostaglandin-F2 $\alpha$; progesterone; cow

\section{Introduction}

In recent studies it has been demonstrated that mature cow (Ursely \& Leymarie, 1979; Koos \& Hansel, 1981), sheep (Fitz et al., 1982), pig (Lemon \& Loir, 1977) and rabbit (Hoyer et al., 1986) luteal tissues consist of at least two morphologically and biochemically distinct cell types that can be separated according to size and differ in their ability to secrete progesterone. In the bovine corpus luteum (CL), preparations of the small cells $(10-22 \mu \mathrm{m}$ in diameter) are about 6 times more responsive to luteinizing hormone $(\mathrm{LH})$ added in vitro than are those of the relatively impure large cells $(>25 \mu \mathrm{m})$ (Ursely \& Leymarie, 1979; Koos \& Hansel, 1981). In sheep the large cells produced more progesterone than the small cells but were unresponsive to $\mathrm{LH}$, dibutyryl cAMP, or agents that stimulate cAMP such as cholera toxin and forskolin (Fitz et al., 1982; Hoyer et al., 1984). In 
the cow CL, the large cells were reported to be marginally responsive to added LH (Ursely \& Leymarie, 1979; Koos \& Hansel, 1981) and it was suggested that the observed responses to LH were due to contaminating small cells in the preparations. These observations suggested that steroidogenesis in these cell types is regulated by different mechanisms, and this may be important in the regulation of the functional lifespan of the CL.

In earlier experiments with enzyme-dispersed total luteal cell preparations, Hansel \& Dowd (1986) and Brunswig et al. (1986) showed that addition of phorbol esters increased progesterone production. Addition of a phorbol ester that does not activate protein kinase $\mathrm{C}$ failed to increase progesterone production (Hansel et al., 1987). Dowd \& Hansel (1987) further substantiated that the stimulatory effect of addition of a phorbol ester on progesterone production by bovine luteal cells is due to protein kinase $\mathrm{C}$ activation by showing that protein kinase $\mathrm{C}$ enzyme activity and specific binding to phorbol ester co-eluted as a single peak when luteal cell cytosolic fractions were chromatographed on DEAE-Sephadex. In total dispersed cell preparations, PGF-2 $\alpha$, like phorbol esters, stimulates progesterone production by bovine luteal cells (Hixon \& Hansel, 1979) by a mechanism that involves the $\mathrm{Ca}^{2+}$-polyphosphoinositol protein kinase $\mathrm{C}\left(\mathrm{Ca}^{2+}-\mathrm{PKC}\right)$ system (Davis et al., 1987a, b).

Work with the large luteal cells has been hampered by lack of a good separation system. Separation methods such as unit gravity sedimentation (Koos \& Hansel, 1981) or elutriation (Fitz et al., 1982) have yielded large cell preparations that are usually contaminated with large numbers of small cells. Production of pure large cell preparations by micromanipulation (Hansel et al., 1987) is slow and tedious. In the present work, we used flow cytometry and unit gravity sedimentation to obtain pure preparations of large and small luteal cells from bovine CL; this development enabled us to compare the influences of various substances on large and small cells from the same corpora lutea.

\section{Materials and Methods}

Tissue dissociation and cell separations. Corpora lutea (CL) were enucleated from normal Holstein heifers on Days $10-12$ of the oestrous cycle (oestrus = Day 0$)$ and immediately placed in cold $\left(4^{\circ} \mathrm{C}\right)$ Medium 199 containing penicillin-streptomycin (100 units penicillin/ml and $100 \mu \mathrm{g}$ streptomycin $/ \mathrm{ml}$ ). Dispersed cell preparations were made and viable cells were determined by counting cells that excluded Trypan blue (Simmons et al., 1976).

Briefly, the luteal tissue was dissociated in collagenase ( $2000 \mathrm{U} / \mathrm{g}$ tissue) in Medium 199 (5 ml/g luteal tissue) at $34^{\circ} \mathrm{C}$. After incubation for $45 \mathrm{~min}$, the medium containing cell suspension was decanted, centrifuged ( $\left.100 \mathrm{~g}, 5 \mathrm{~min}\right)$, and the cells were resuspended in fresh medium. Fresh medium containing collagenase was added to the remaining undissociated tissue and dissociation was continued for an additional $45 \mathrm{~min}$. The cells from this dissociation were also centrifuged, and cells from both dissociations were pelleted. Centrifugation was repeated three times, and the cells were resuspended in cold fresh medium after each centrifugation. The cells were filtered through an artist's silkscreen ( $150 \mu \mathrm{m}$ pore diameter) followed by a monofilament nylon mesh $(44 \mu \mathrm{m})$ to remove clumps of undissociated tissue. Cells were separated by unit gravity sedimentation (Koos \& Hansel, 1981) which yielded preparations that were $95-100 \%$ small cells. These fractions of small cells were free of large cells but slightly contaminated with endothelial cells. The fraction containing large cells was collected and sorted in order to obtain pure fractions of large cells. Purified small cells were also used during the analysis by flow cytometry to help identify the window containing the large cells and to determine the effects, if any, of the laser beam on cell viability.

Flow cytometry. Flow analysis and sorting of the luteal cells was carried out on a BD FACS 440 (Becton Dickinson, Mountain View, CA) using an argon ion laser (Spectra Physics model 164-05, Mountain View, CA) with Medium 199 as sheath fluid. The sheath pressure was $96.5 \mathrm{kPa}$ and the injector tip was $70 \mu \mathrm{m}$ in diameter. Cells were excited with the $488 \mathrm{~nm}$ line at approximately $150 \mathrm{~mW}$ output. Relative autofluorescence was measured at $578 \mathrm{~nm}$ using a $550 \mathrm{~nm}$ longpass filter in conjunction with a $600 \mathrm{~nm}$ shortpass filter (both from Corion Corp., Holliston, MA), while forward low-angle scatter was determined using a $488 / 10 \mathrm{~nm}$ bandpass filter and a 1.6 optical density neutral filter (Becton Dickinson).

A computer (Digital Electronics Corp. PDP 11/23) interfaced with the FACS was used to compute the 2-dimensional distribution of any test population of cells with respect to forward low-angle scatter and the log of the relative autofluorescence. The subsequent cytograms were displayed on an associated visual display unit with relative autofluorescence measurements being expressed as log units on the ordinate, and forward low-angle scatter measurements as linear units on the abscissa. Sort rates for experiments were $400-600 \mathrm{cells} / \mathrm{sec}$. The sorting windows were characterized such that cells with high relative autofluorescence were isolated and cell clumps, small luteal cells, and 
cells less than $10 \mu \mathrm{m}$ in diameter were excluded. The purity and viability of sorted cells were determined by light microscopy on the basis of size. This method of classification of the cells has been validated by electron microscopy to identify each cell type (Koos \& Hansel, 1981; Hansel et al., 1987; Hansel \& Dowd, 1986).

Incubations and progesterone assay. Treatments $(10 \mu \mathrm{l})$ were added $(0 \mathrm{~h})$ and aliquants were removed after $10 \mathrm{~min}$ preincubation. Incubations were conducted with $1 \times 10^{5}$ viable small luteal cells per $0.5 \mathrm{mi}$ Medium 199 for $2 \mathrm{~h}$ while $1 \times 10^{3}$ viable large luteal cells were incubated for $4 \mathrm{~h}$. Samples were collected and frozen at $-20^{\circ} \mathrm{C}$ until assayed for progesterone. There were 3 or 4 replicates of each treatment for each CL for large and small cells respectively. Net progesterone accumulation, representing medium plus cells, was the difference between concentrations at 0 and 2 or $4 \mathrm{~h}$.

Progesterone concentrations were determined by radioimmunoassay (Beal et al., 1980). The antiserum used was specific for progesterone, cross-reacting with $5 \beta$-dihydroprogesterone $(13.6 \%)$, 20ß-dihydroprogesterone $(5 \cdot 7 \%)$, $17 \alpha$-hydroxyprogesterone $(4.4 \%), 20 \alpha$-dihydroprogesterone $(1.8 \%), 5 \alpha$-dihydroprogesterone $(1.6 \%)$ and corticosterone $(1.4 \%)$. All other steroids tested cross-reacted $<1 \%$. The sensitivity was $10 \mathrm{pg} /$ tube and the intraassay coefficient of variation was $4.5 \%$ at $60 \mathrm{pg} /$ tube (18 assays). Interassay coefficients of variation were $8.3 \%$ and $7.6 \%$ at 60 and $300 \mathrm{pg} /$ tube, respectively. The samples from each CL were analysed in the same assay.

Reagents. Medium 199 and penicillin-streptomycin were purchased from Grand Island Biological Co. (Grand Island, NY). Collagenase (CLS) was obtained from Worthington Biochemicals (Freehold, NJ), 4 $\beta$-phorbol 12, 13-dibutyrate ( $\left.\mathrm{PBt}_{2}\right)$, forskolin, 8-bromo-adenosine 3,5-cyclic AMP (8-Br-cAMP), and phospholipase C (Type XIII, 2500 Units $/ \mathrm{mg}$ ) were purchased from Sigma Chemical Co. (St Louis, MO). Phospholipase $\mathrm{C}$ suspended in $3.2 \mathrm{M}-\left(\mathrm{NH}_{4}\right)_{2} \mathrm{SO}_{4}$ was diluted to $100 \mathrm{U} / \mathrm{ml}$ in $150 \mathrm{~mm}-\mathrm{NaCl}$ and stored at $0-5^{\circ} \mathrm{C}$. Bovine $\mathrm{LH}(\mathrm{NIH}-\mathrm{B} 9-\mathrm{LH})$ was supplied by NIH. Prostaglandin F-2 $\alpha$ (tromethamin salt) was obtained from Upjohn Co. (Kalamazoo, MI).

Statistics. Paired $t$-test and analysis of variance were used to determine the significance of treatment. The differences between groups were evaluated with Duncan's multiple range test.

\section{Results}

\section{Flow cytometry and cell sorting}

The use of flow cytometry made it possible to isolate fractions of highly purified large cell preparations. In Fig. 1 histograms of known purified small luteal cells obtained by unit gravity sedimentation (Koos \& Hansel, 1981) are compared with the large cell enriched fraction. The

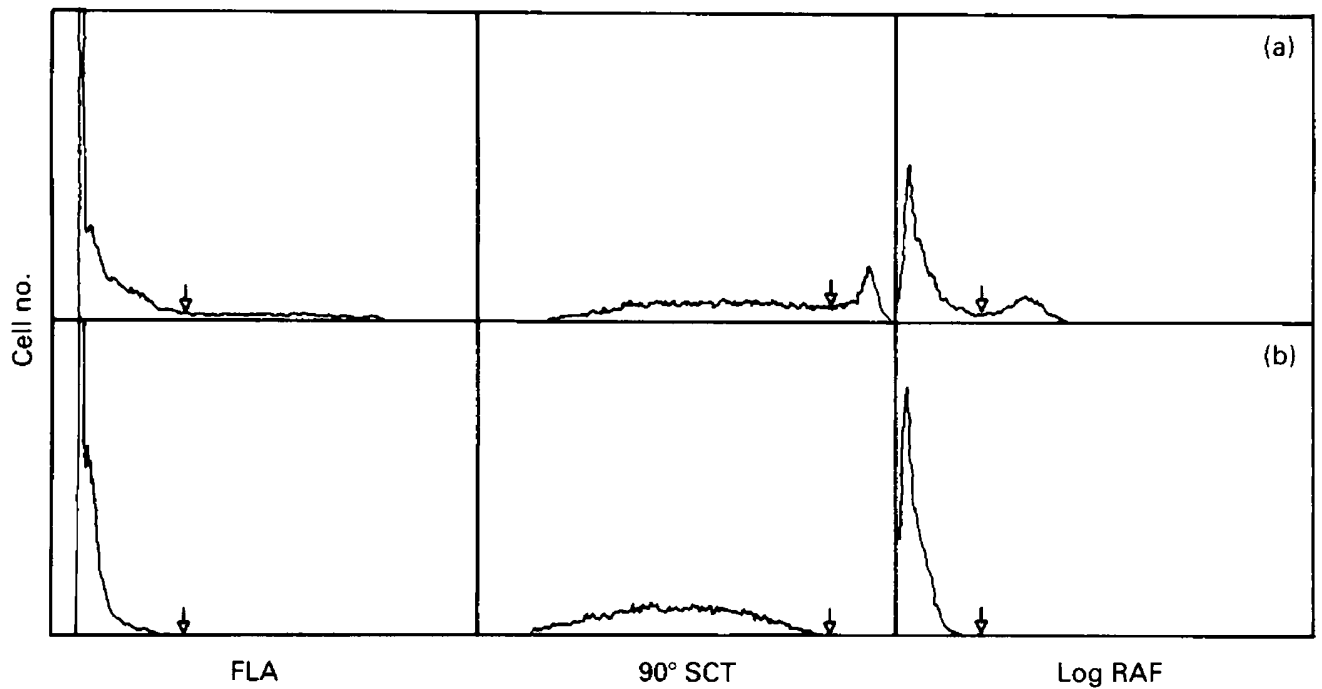

Fig. 1. Histograms of forward low-angle (FLA) light scattering, $90^{\circ}$ scatter $\left(90^{\circ} \mathrm{SCT}\right)$ and relative autofluorescence (RAF) of an impure large luteal cell fraction (a) compared with purified small luteal cells (b). The arrows indicate the cut-off points used to discriminate each cell type from the other. 


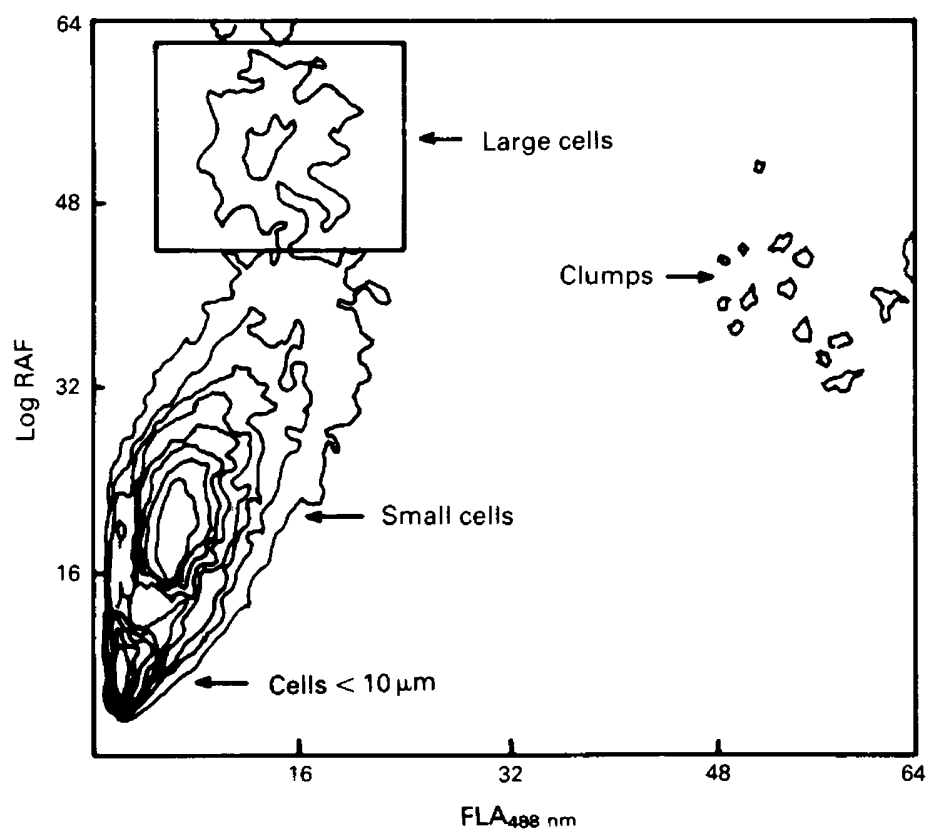

Fig. 2. Two-parameter contour display of luteal cells using FLA at $488 \mathrm{~nm}$ (abscissa) versus $\log$ RAF (ordinate). The window setting used for sorting large luteal cells relative to the position of the other cell types is shown. The position of the cell types (small cells, cells $<10 \mu \mathrm{m}$ and clumps) was obtained by sorting the cells from each of the areas indicated. Similar displays were observed in 8 independent experiments.

presence of large cells caused significant differences in forward low-angle scatter, $90^{\circ}$ scatter, and relative autofluorescence, after excitation at $488 \mathrm{~nm}$. A dual parameter mode, using forward lowangle scatter versus log relative autofluorescence was used to obtain the window (Fig. 2) for sorting the large luteal cells from other cells. Analysis of the total number of cells in these experiments indicated that the window containing pure preparations of large cells showed a high relative autofluorescence and consisted of only $2-6 \%$ of all the cells.

In unseparated preparations of mid-cycle (Day 10-12) luteal cells, the large luteal cells constituted only $5 \cdot 1 \pm 0 \cdot 8 \%$ (mean \pm s.e., $n=8$ ) of all cells between 10 and $50 \mu \mathrm{m}$ in diameter. In the large cell-enriched fraction obtained by unit gravity sedimentation, large cells comprised only $25-35 \%(28 \pm 4 \%, n=10)$ of cells in the preparation. In contrast, the purity of large cells (Fig. 3$)$ obtained by cell sorting was $90-99 \%(92 \pm 1 \%, n=10)$. Examination of the cells by electron microscopy revealed no morphological alterations due to sorting. Out of $10 \mathrm{CL}, 2$ failed to give a fluorescent signal sufficient to allow for a good separation. Sorting of cells from these two CL was difficult because the cells fluoresced weakly and the purity of the preparations obtained was $85 \%$. These cells were not used in the incubations reported here. Only cell preparations with a purity $>90 \%$ were used. The main contaminants of the preparations after sorting were occasional small cells attached to large luteal cells; this occurred in some preparations, while in others it was nonexistent. Occasional clumps of small cells and endothelial cells occurred but these were $<1 \%$ of the total cells. A typical sorting experiment resulted in 20-25 large luteal cells for every contaminating cell. The viability of the large cells was relatively low, ranging from 46 to $65 \%(56 \pm 2 \%, n=10)$. This was comparable to the viability of the large cell fraction before sorting, which was $63 \pm 3 \%$ $(n=8)$. 


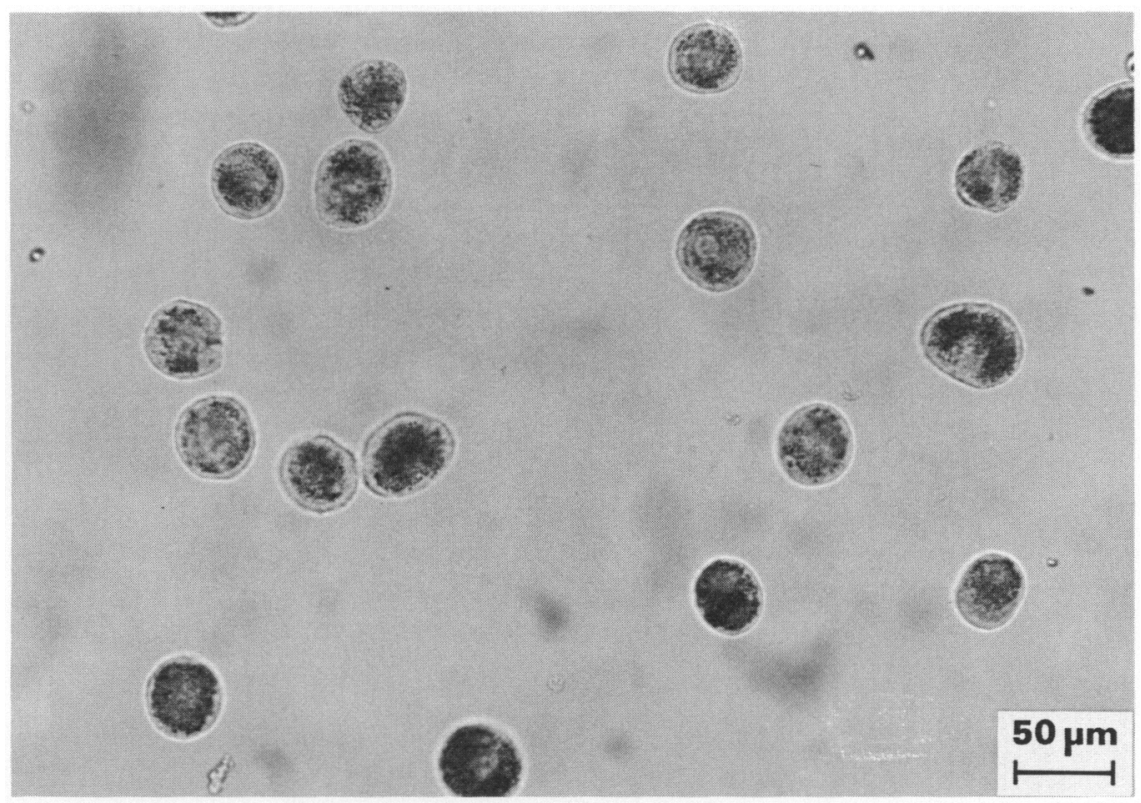

Fig. 3. Photomicrograph of large luteal cells obtained by fluorescent activated cell sorting.

\section{Effect of $L H$}

Only very high doses of $\mathrm{LH}(100 \mathrm{ng} / \mathrm{ml}$ or more $)$ increased $(P<0.05)$ progesterone production in the large cells. Progesterone production for $0,5,10,100$ and $1000 \mathrm{ng} \mathrm{LH} / \mathrm{ml}$ was $1635 \pm 318$, $2118 \pm 699,2209 \pm 256,2662 \pm 459$ and $3386 \pm 335 \mathrm{pg} / 10^{3}$ cells $/ 4 \mathrm{~h}$, respectively. In contrast, treatment of small cells with low doses of LH $(1$ and $5 \mathrm{ng} / \mathrm{ml})$ stimulated $(P<0.05)$ progesterone production 6-fold (Table 1). Progesterone production was also stimulated 2-fold in large cells in the presence of 8-Br-cAMP $(0.5 \mathrm{mM})$ and forskolin $(1.0 \mu \mathrm{M})$, as shown in Fig. 4.

\section{Effects of PGF-2a on progesterone production}

When the small cells were incubated with various concentrations of PGF-2 $\alpha(0,10,100$ and $1000 \mathrm{ng} / \mathrm{ml}$ ), a dose-dependent increase in progesterone production resulted (Table 2). The progesterone stimulated by $\mathrm{LH}(1 \mathrm{ng} / \mathrm{ml})$ was increased further $(P<0.05)$ when PGF-2 $\alpha$ was added.

In contrast, PGF- $2 \alpha$, used at $1000 \mathrm{ng} / \mathrm{ml}$, had no effect on basal progesterone production by the large cells (Fig. 4). However, progesterone production stimulated by LH, 8-Br-cAMP or forskolin was clearly inhibited $(P<0.05)$ by PGF- $2 \alpha$.

\section{Effects of phorbol ester, $\mathrm{PBt}_{2}$}

The phorbol ester, $\mathrm{PBt}_{2}$, stimulated $(P<0.05)$ progesterone in small cells at a concentration of $50 \mathrm{nM}$; higher concentrations had no additional effect on steroidogenesis (Table 1). $\mathrm{PBt}_{2}$ had no effect on LH-stimulated steroidogenesis. Similarly, $\mathbf{P B t}_{2}$ plus the calcium ionophore A23187 resulted in progesterone production similar to $\mathrm{PBt}_{2}$ alone (data not shown). As expected, the inactive phorbol ester, phorbol-13 monoacetate (PBAc), had no effect on basal or LH-stimulated progesterone synthesis. 
Table 1. The effects of the active phorbol ester, $\mathrm{PBt}_{2}$, or the inactive phorbol ester, phorbol-13 monoacetate (PBAc), with or without $\mathrm{LH}$ ( 1 or $5 \mathrm{ng} / \mathrm{ml}$ ), on net progesterone production (ng/ $10^{5}$ cells $/ 2 \mathrm{~h}$ ) by small luteal cells

\begin{tabular}{|c|c|c|c|}
\hline $\begin{array}{l}\text { Phorbol } \\
\text { ester (nM) }\end{array}$ & $-\mathrm{LH}$ & $\begin{array}{c}+\mathrm{LH} \\
(1 \mathrm{ng} / \mathrm{ml})\end{array}$ & $\begin{array}{c}+\mathrm{LH} \\
(5 \mathrm{ng} / \mathrm{ml})\end{array}$ \\
\hline \multicolumn{4}{|l|}{$\mathrm{PBt}_{2}$} \\
\hline 0 & $10 \cdot 14 \pm 2.97^{\mathrm{a}}$ & $58.47 \pm 4.65^{\mathrm{e}}$ & $66.34 \pm 5.72^{e}$ \\
\hline l & $13.95 \pm 4 \cdot 15^{a, b . c}$ & $54 \cdot 22 \pm 4 \cdot 64^{e}$ & - \\
\hline 10 & $11.98 \pm 3 \cdot 18^{\mathrm{a}}$ & $52.63 \pm 4.03^{\mathrm{e}}$ & - \\
\hline 20 & $13.53 \pm 3.34^{\mathrm{a}, \mathrm{b}}$ & $54.73 \pm 2.02^{\mathrm{e}}$ & $59 \cdot 70 \pm 2 \cdot 0^{\mathrm{e}}$ \\
\hline 50 & $18.07 \pm 5.07^{\mathrm{c} . \mathrm{d}}$ & $51.91 \pm 2.78^{\mathrm{e}}$ & 二 \\
\hline 100 & $17 \cdot 36 \pm 4 \cdot 24^{b, c, d}$ & $52.14 \pm 0.95^{\mathrm{c}}$ & $57.34 \pm 0.66^{\mathrm{e}}$ \\
\hline 200 & $18.83 \pm 4.26^{\mathrm{d}}$ & $54.97 \pm 2.01^{\mathrm{e}}$ & - \\
\hline 500 & $19 \cdot 66 \pm 4 \cdot 50^{\mathrm{d}}$ & $53.42 \pm 1 \cdot 30^{\mathrm{e}}$ & - \\
\hline \multicolumn{4}{|l|}{ PBAc } \\
\hline 100 & $10 \cdot 2 \pm 2 \cdot 9^{\mathrm{a}}$ & $58 \cdot 28 \pm 1 \cdot 13^{\mathrm{e}}$ & - \\
\hline
\end{tabular}

Values are mean \pm s.e.m. for $5 \mathrm{CL}(-\mathrm{LH})$ or $3 \mathrm{CL}(+\mathrm{LH})$ observations.

Values with the different superscripts differ $(P<0.05)$.

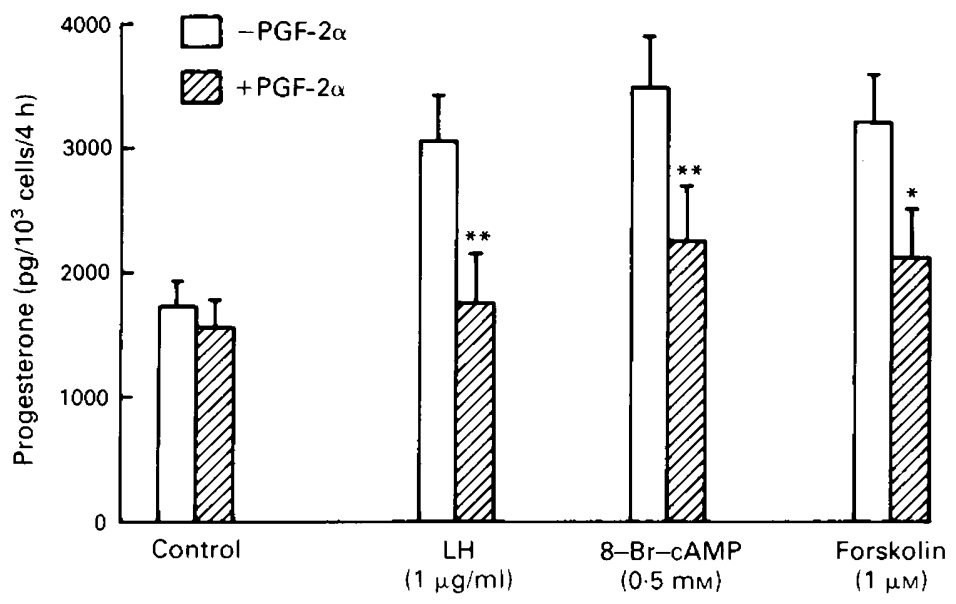

Fig. 4. Inhibition by PGF- $2 \alpha(1 \mu \mathrm{g} / \mathrm{ml})$ of the stimulatory effects of $\mathrm{LH}, 8-\mathrm{Br}-\mathrm{cAMP}$ and forskolin on progesterone production by large luteal cells. Values are means \pm s.e. for $5 \mathrm{CL} .{ }^{*} P<0.05,{ }^{* *} P<0.01$, compared with progesterone production stimulated with $\mathrm{LH}$, 8-Br-cAMP and forskolin in the absence of PGF-2 $\alpha$.

In a related experiment (Table 3$)$, the addition of exogenous phospholipase $\mathrm{C}(2 \mathrm{U} / \mathrm{ml})$ also stimulated progesterone production in the small cells by nearly 2-fold compared with controls $(P<0.05)$. Surprisingly, in the presence of $\mathrm{LH}$, this enzyme caused a significant $(P<0.05)$ inhibition of progesterone synthesis.

In contrast to results with small cells, addition of phorbol ester ( 20 or $100 \mathrm{nM}$ ) to large cells had no effect on progesterone production in the absence or presence of $5 \mathrm{ng} \mathrm{LH} / \mathrm{ml}$ or $1 \mu \mathrm{g} \mathrm{LH} / \mathrm{ml}$ (Table 4). 
Table 2. Effects of prostaglandin F-2 $\alpha$ on net production of progesterone (ng/ $10^{5}$ cells) by small luteal cells incubated for $2 \mathrm{~h}$ in the absence or presence of $\mathrm{LH}(1 \mathrm{ng} / \mathrm{ml})$

\begin{tabular}{ccc}
\hline $\begin{array}{c}\text { PGF-2 } \alpha \\
(\mathrm{ng} / \mathrm{ml})\end{array}$ & $-\mathrm{LH}$ & $\begin{array}{c}+\mathrm{LH} \\
(1 \mathrm{ng} / \mathrm{ml})\end{array}$ \\
\hline 0 & $19 \cdot 88 \pm 3 \cdot 18(6)^{\mathrm{a}}$ & $82.51 \pm 9.74(4)^{\mathrm{d}}$ \\
10 & $28.48 \pm 4.97(6)^{\mathrm{a}}$ & $88.75 \pm 19.85(4)^{\mathrm{d}}$ \\
100 & $36.90 \pm 7.27(6)^{\mathrm{b}}$ & $95.79 \pm 11.68(4)^{\mathrm{d}, \mathrm{e}}$ \\
1000 & $44 \cdot 19 \pm 9 \cdot 28(6)^{\mathrm{b}, \mathrm{c}}$ & $99.43 \pm 7.73(4)^{\mathrm{e}}$ \\
\hline Values are mean \pm s.e.m. for the no. of CL in \\
parentheses. \\
Values within columns with different superscripts are \\
significantly different $(P<0.05)$.
\end{tabular}

Table 3. The effects of phospholipase $\mathrm{C}(2 \mathrm{U} / \mathrm{ml})$ on net progesterone production $\left(\mathrm{ng} / 10^{5}\right.$ cells $/ 2 \mathrm{~h}$ ) by small luteal cells

\begin{tabular}{lcc}
\hline \multicolumn{1}{c}{ Treatment } & $-\mathrm{LH}$ & $\begin{array}{c}+\mathrm{LH} \\
(\mathrm{l} \mathrm{ng} / \mathrm{ml})\end{array}$ \\
\hline Controls & $18 \cdot 90 \pm 4 \cdot 32^{\mathrm{a}}$ & $82 \cdot 51 \pm 9 \cdot 74^{\mathrm{c}}$ \\
Phospholipase C & $32 \cdot 79 \pm 3 \cdot 29^{\mathrm{b}}$ & $54 \cdot 99 \pm 5 \cdot 21^{\mathrm{d}}$ \\
\hline
\end{tabular}

Values are mean \pm s.e.m. for 4 corpora lutea.

Values with different superscripts are significantly different $(P<0.05)$.

Table 4. The effects of phorbol ester, $\mathrm{PBt}_{2}$, with or without $\mathrm{LH}$, on net progesterone production $\left(\mathrm{pg} / 10^{3}\right.$ cells $\left./ 4 \mathrm{~h}\right)$ by large luteal cells

\begin{tabular}{rccc}
\hline $\begin{array}{r}\mathrm{PBt}_{2} \\
(\mathrm{nM})\end{array}$ & $-\mathrm{LH}$ & $\begin{array}{c}\mathrm{LH} \\
(5 \mathrm{ng} / \mathrm{ml})\end{array}$ & $\begin{array}{c}\mathrm{LH} \\
(\mathrm{l} \mathrm{gg} / \mathrm{ml})\end{array}$ \\
\hline 0 & $2231 \pm 549$ & $2915 \pm 617$ & $3447 \pm 477$ \\
20 & $2224 \pm 554$ & $2601 \pm 527$ & \pm \\
100 & $2403 \pm 369$ & $2700 \pm 631$ & $3413 \pm 480$ \\
\hline
\end{tabular}

Values are mean \pm s.e.m. for 5 corpora lutea.

\section{Discussion}

These experiments demonstrate the successful use of flow cytometry to obtain highly purified preparations of large bovine luteal cells by utilizing autofluorescence and forward light scatter as characteristic properties of these cells. It was impossible to separate cells without prior separation by unit gravity sedimentation. Our initial studies showed that the large luteal cells emit light 
maximally at $578 \mathrm{~nm}$ when excited at $488 \mathrm{~nm}$. We used forward low-angle light scatter at $488 \mathrm{~nm}$, which is a function of cell size and shape, and the autofluorescence as dual parameters for cell sorting.

The purity of large cells obtained by this method is clearly superior to that of preparations produced by unit gravity sedimentation (Koos \& Hansel, 1981) or elutriation (Fitz et al., 1982; Harrison et al., 1987). Unit gravity sedimentation yielded a large cell-enriched preparation which had $75 \%$ small cell contamination (Koos \& Hansel, 1981), while elutriation yielded fractions of large cells that were $77 \pm 3 \%$ pure (Harrison et al., 1987). The yield of pure cells from flow cytometry used in this study was $90-99 \%$.

The relatively low viability of the large cells was not caused by the cell sorter. The high levels of progesterone synthesis by the large cells during incubation indicates that most of these cells remained viable during incubation. Net progesterone production per cell was similar to that reported by Koos \& Hansel (1981) for impure fractions of large cells.

The results, summarized in Table 5, clearly demonstrate a differential control of production of progesterone in large and small luteal cells in the cow. These results and those previously cited show that, apart from the well known cAMP second messenger system, the $\mathrm{Ca}^{2+}$-PKC system (Nishizuka, 1984) is operational in the small luteal cells. The approximate doubling of progesterone biosynthesis seen previously with the total dispersed cell preparations (Hansel \& Dowd, 1986) was observed in the present experiments with the small cells after the addition of the phorbol ester, $\mathrm{PBt}_{2}$, or phospholipase $\mathrm{C}$. However, the calcium ionophore did not synergize with phorbol ester to increase progesterone production in the small cells, as suggested for other systems (Nishizuka, 1986). This suggests that in these cells, as reported for rat luteal cells (Baum \& Rosberg, 1987), activation of protein kinase $\mathrm{C}$ stimulates progesterone production independently of elevation of calcium by ionophores.

Table 5. Summary of the effects of LH, PGF-2 $\alpha$, a phorbol ester $\left(\mathrm{PBt}_{2}\right)$ and phospholipase $\mathrm{C}$ in the control of production of progesterone synthesis in small and large bovine luteal cells

\begin{tabular}{lcc}
\hline & \multicolumn{2}{c}{ Type of luteal cell } \\
\cline { 2 - 3 } Compound(s) added & Small & Large \\
\hline LH & +++ & + \\
PGF-2 $\alpha$ & + & 0 \\
PBt & + & 0 \\
PGF-2 $\alpha+$ LH & ++++ & - \\
PBt + LH & +++ & 0 \\
Phospholipase C & + & ND \\
\hline (+) = a 2-fold increase and $(-)$ a $50 \%$ & decrease in \\
progesterone synthesis; $0=$ no effect; & ND $=$ not \\
determined. &
\end{tabular}

The failure of an active phorbol ester to stimulate progesterone synthesis by the large luteal cells in these experiments, together with the fact that the stimulation found after adding the phorbol ester to small cells was equal to that found after its addition to total cell preparations, suggest that protein kinase $\mathrm{C}$ plays no essential role in large cells. However, further experiments including direct measurements of enzyme activity are needed to establish this point.

There were clear differences between the effects of $\mathrm{PBt}_{2}$ and phospholipase C. $\mathrm{PBt}_{2}$ increased progesterone synthesis when added at a level of $50 \mathrm{nM}$ or higher, whereas phospholipase $\mathrm{C}$, at the level used, was inhibitory to LH-stimulated progesterone production. Addition of phospholipase C increases polyphosphoinositide hydrolysis in luteal cells (Leung et al., 1986). Other metabolic products, including prostanoids, are formed during this process via generation of diacylglycerol 
(Majerus et al., 1986). These prostanoids, including the products of the lipoxygenase pathway may exert an inhibitory action on steroidogenesis. For example, in an earlier study Milvae et al. (1986) showed that a product of the lipoxygenase pathway, 5-HETE, causes a reduction in basal and LH-stimulated progesterone synthesis in dispersed luteal cells. The predominant effect of $\mathrm{PBt}_{2}$ is protein kinase C activation (Nishizuka, 1986). PBAc, however, has been shown (Takai et al., 1984) not to activate protein kinase $\mathrm{C}$, and it failed to stimulate progesterone production in small luteal cells in these experiments.

A major result of these experiments is the demonstration that the previously reported (Hixon \& Hansel, 1979) stimulation of progesterone production by PGF-2 $\alpha$ in total dispersed cells is a property of the small, theca-derived cells. Benhäim et al. (1987) also showed that PGF-2 $\alpha$ stimulated progesterone production in the small luteal cells. However, in contrast to our results, in which the LH-stimulated increase in small cells was further enhanced by PGF-2 $\alpha$, progesterone production was inhibited in LH-stimulated cells in their studies which were carried out on CL of pregnant animals.

The maximal response achieved with PGF-2 $\alpha$ in small cells was similar to that achieved by addition of phorbol ester $\left(\mathrm{PBt}_{2}\right)$ or phospholipase C. PGF- $2 \alpha$ invokes its effect by a mechanism that appears to be independent of increases in cAMP (Speroff \& Ramwell, 1970; Marsh, 1971; Davis et al., 1987a). Davis et al. (1987b) demonstrated that PGF-2 $\alpha$ stimulates phosphatidylinositol 4,5-bisphosphate hydrolysis in the small cells, a process that also produces diacylglycerol, which activates protein kinase C (Nishizuka, 1986). Thus, the stimulatory effect of PGF-2 $\alpha$ on progesterone in bovine luteal cells appears to be mediated by a mechanism that involves activation of protein kinase $C$ in the small luteal cells of theca cell origin (Alila \& Hansel, 1984). However, it should be noted that PGF-2 $\alpha$ but not $\mathrm{PBt}_{2}$, enhanced $\mathrm{LH}$-stimulated progesterone production by the small cells. Reasons for these differences are unknown, but mechanisms of action other than protein kinase $\mathrm{C}$ activation may be involved.

Factors that regulate or maintain the high levels of progesterone production by the large cells are poorly understood. Our data showing that the large cells are responsive to stimulation by high levels (>100 ng/ml) of LH, are qualitatively similar to those of Ursely \& Leymarie (1979) and Koos \& Hansel (1981) who used impure preparations of large cells. In contrast, small cells increased their progesterone output 6 -fold in response to $\mathrm{LH}$, and the maximum stimulatory dose was $5 \mathrm{ng} / \mathrm{ml}$ (Table 1).

Chegini et al. (1984) showed that basal, hCG- or cAMP-stimulated progesterone production and hCG binding were similar in the large and small luteal cells of CL of pregnancy. This finding is not surprising, considering that the majority of the large cells during pregnancy are derived from the small luteal cells of thecal origin (Alila \& Hansel, 1984). Generally, cells from CL of pregnancy are less responsive to added $\mathrm{LH}$ than are those from CL collected during the oestrous cycle (Shemesh \& Hansel, 1983).

Progesterone synthesis in large cells was stimulated 2-fold by forskolin and 8-Br-cAMP, suggesting that the cAMP system in these cells is indeed functional. Forskolin exerts its stimulatory effects mainly on the catalytic unit of adenylate cyclase (Seamon \& Daly, 1981), although evidence in other tissues suggests that it may also stimulate the $G / F$ protein regulation of the enzyme (Insel et al., 1982). We do not know if all the large cells, or only some of them (the theca-derived cells, Alila \& Hansel, 1984) are responsive. It is possible that the response to LH and other cAMP regulatory agents is due to the fact that, in the cow, the large luteal cells of theca cell derivation retain functional $\mathrm{LH}$ receptors.

Prostaglandin F-2 $\alpha$ alone had no effect on basal progesterone production by the large luteal cells; however, it inhibited $\mathrm{LH}$, forskolin and 8-Br-cAMP-stimulated progesterone production. The ability of PGF-2 $\alpha$ to inhibit forskolin or 8-Br-cAMP-stimulated progesterone suggests that its effect occurs at some step distal to the intracellular generation of cAMP. Our observations on the effects of PGF-2 $\alpha$ on large cells are similar to those of Pate \& Condon (1984) who showed that PGF-2 $\alpha$ inhibited progesterone synthesis in unseparated cultured bovine luteal cells. The inhibitory 
effect of PGF-2 $\alpha$ on the large cells is in sharp contrast to its effect on small luteal cells, in which it stimulates progesterone synthesis, both alone and in combination with $\mathrm{LH}$.

An implication of these findings on the function of the CL in vivo is that the large cells are the targets of the luteolytic action of PGF-2 $\alpha$. The preponderance of the small cells, found in CL during early stages of the estrous cycle and their ability to respond to PGF-2 $\alpha$ by increasing progesterone production suggest that prostaglandins normally present in the bovine CL (Shemesh \& Hansel, 1975; Milvae \& Hansel, 1983) may play a paracrine role in the regulation of progesterone production.

The work described was supported by USDA Grant 85-CRCR-1-1830 and funds provided by the Cornell Biotechnology Institute. We thank Ray Saatman, David King, Douglas Bianchi for technical assistance and Virginia Slator for assistance in preparation of the manuscript.

\section{References}

Alila, H.W. \& Hansel, W. (1984) Origin of different cell types in the bovine corpus luteum as characterized by specific monoclonal antibodies. Biol. Reprod. 31, 1015-1025.

Baum, M.S. \& Rosberg, S. (1987) A phorbol ester, phorbol 12-myristate 13-acetate and a calcium ionophore, A23187, can mimic the luteolytic effect of prostaglandin F-2 $\alpha$ in isolated rat luteal cells. Endocrinology 120, 1019-1026.

Beal, W.E., Milvae, R.A. \& Hansel, W. (1980) Oestrous cycle length and plasma progesterone concentrations following administration of prostaglandin F-2a early in the bovine oestrous cycle. J. Reprod. Fert. 59, 393-396.

Benhäim, A., Bonnamy, P.J., Papadopoulos, V., Mittre, H. \& Leymaire, P. (1987) In vitro action of PGF-2 $\alpha$ on progesterone and CAMP synthesis in small bovine luteal cells. Prostaglandins 33, 227-239.

Brunswig, F., Mukhopadhyay, A.K., Budnick, L.T., Bohnet, H.G. \& Leidenberger, F.A. (1986) Phorbol ester stimulates progesterone production by isolated bovine luteal cells. Endocrinology 118, 743-749.

Chegini, N., Ramani, N. \& Rao, Ch.V. (1984) Morphological and biochemical characterization of small and large bovine luteal cells during pregnancy. Molec cell. Endocr. 37, 89-102.

Davis, J.S., Weakland, L.L., Weiland, D.A., Farese, R.V. \& West, L.A. (1987a) Prostaglandin F-2 $\alpha$ stimulates phosphatidyl/inositol 4,5-bisphosphate hydrolysis and mobilizes intracellular $\mathrm{Ca}^{2+}$ in bovine luteal cells. Proc. natn. Acad. Sci., U.S.A. 84, 3728-3732.

Davis, J.S., West, L.A. \& Alila, H.W. (1987b) Inositol triphosphate $\left(\mathrm{IP}_{3}\right)$ anc cAMP accumulation in bovine large and small luteal cells: effects of LH and PGF-2 2. Biol. Reprod. 36 (Suppl. 1), 162, Abstr.

Dowd, J.P. \& Hansel, W. (1987) Phorbol ester receptors in bovine luteal cells. Biol. Reprod. 36 (Suppl.) 162, Abstr.

Fitz, T.A., Mayan, M.H., Sawyer, H.R. \& Niswender, G.D. (1982) Characterization of two steroidogenic cell types in the ovine corpus luteum. Biol. Reprod. 27, 703-711.

Hansel, W. \& Dowd, J.P. (1986) New concepts of the control of corpus luteum function. J. Reprod. Fert. 78, 755-768.
Hansel, W., Alila, H.W., Dowd, J.P. \& Yang, X. (1987) Control of steroidogenesis in small and large bovine luteal cells. Aust. J. biol. Sci. 40, 331-351.

Harrison, L.M., Kenny, N. \& Niswender, G.D. (1987) Progesterone production, $\mathrm{LH}$ receptors and oxytocin secretion by ovine luteal cell types on Days 6,10 and 15 of the oestrous cycle and Day 15 of pregnancy. $J$. Reprod. Fert. 79, 539-548.

Hixon, J.E. \& Hansel, W. (1979) Effects of prostaglandin $F-2 \alpha$, estradiol and luteinizing hormone in dispersed cell preparations of bovine corpora lutea. In Ovarian Follicular and Corpus Luteum Function, pp. 613-620. Eds C. P. Channing \& J. M. Marsh. Plenum, New York.

Hoyer, P.B., Fitz, T.A. \& Niswender, G.D. (1984) Hormone-independent activation of adenylate cyclase in large steroidogenic ovine luteal cells does not result in increased progesterone secretion. Endocrinology 114, 604-608.

Hoyer, P.B., Keyes, P.L. \& Niswender, G.D. (1986) Size distribution and hormonal responsiveness of dispersed rabbit luteal cells during pseudopregnancy. Biol. Reprod. 34, 905-910.

Insel, P.A., Stengel, D., Terry, N. \& Hanoune, J. (1982) Regulation of adenylate cyclase of human platelet membranes by forskolin. J. biol. Chem. 257, 7485-7490.

Koos, R.D. \& Hansel, W. (1981) The large and small cells of the bovine corpus luteum: ultrastructural and functional differences. In Dynamics of Ovarian Function, pp. 197-203. Eds N. B. Schwartz \& M. Hunzicker-Dunn. Raven Press, New York.

Lemon, M. \& Loir, M. (1977) Steroid release in vitro by two luteal cell types in corpus luteum of pregnant sow. J. Endocr. 72, 351-359.

Leung, P.C.K., Minegishi, T., Ma, F., Zhou, F. \& HoYuen, B. (1986) Induction of polyphosphoinositide breakdown in rat corpus luteum by prostaglandin F-2 $\alpha$. Endocrinology 119, 12-18.

Majerus, P.W., Connolly, T.M., Deckmyn, H., Ross, T.S., Bross, T.E., Ishii, H., Bansal, V.S. \& Wilson, D.B. (1986) The metabolism of phosphoinositidederived messenger molecules. Science, N.Y. 234, 1519-1526.

Marsh, J. (1971) The effect of prostaglandins on 
adenylate cyclase of the bovine corpus luteum. Ann N.Y. Acad. Sci. 180, 416-425.

Milvae, R.A. \& Hansel, W. (1983) Prostacyclin, prostaglandin F-2 $\alpha$ and progesterone production by bovine luteal cells during the estrous cycle. Biol. Reprod. 29, 1063-1068.

Milvae, R.A., Alila, H.W. \& Hansel, W. (1986) Involvement of lipoxygenase products of arachidonic acid metabolism in bovine luteal function. Biol. Reprod. 35, $1210-1215$.

Nishizuka, Y. (1984) Turnover of inositol phospholipids and signal transduction. Science, N.Y.225, 1365-1367.

Nishizuka, Y. (1986) Studies and perspectives of protein kinase C. Science, N.Y. 233, 305-312.

Pate, J.L. \& Condon, W.A. (1984) Effects of prostaglandin F-2 $\alpha$ on agonist-induced progesterone production in cultured bovine luteal cells. Biol. Reprod. 31, $427-435$.

Seamon, K. \& Daly, J.W. (1981) Activation of adenylate cyclase by the diterpene forskolin does not require the guanine nucleotide regulatory protein. J. biol. Chem. 256, 979-981.

Shemesh, M. \& Hansel, W. (1975) Levels of prostaglandin $F(P G F)$ in bovine endometrium, uterine venous, ovarian arterial and jugular plasma during the estrous cycle. Proc. Soc. exp. Biol. Med. 148, 123-126.

Shemesh, M. \& Hansel, W. (1983) Causes for the decline in steroidogenic capability of bovine CL during late pregnancy. Biol. Reprod. 28 (Suppl. 1), 77, Abstr.

Simmons, K.R., Caffrey, J.O., Phillips, J.L., Abel, J. \& Niswender, G.D. (1976) A simple method for preparing suspensions of luteal cells. Proc. Soc. exp. Biol. Med. 148, 123-126.

Speroff, L. \& Ramwell, P.W. (1970) Prostaglandin stimulation of in vitro progesterone synthesis. J. clin. Endocr. Metab. 30, 345-350.

Takai, Y., Kikkawa, U., Kaibuchi, K. \& Nishizuka, Y. (1984) Membrane phospholipid metabolism and signal transduction for protein phosphorylation. In Advances in Cyclic Nucleotide and Protein Phosphorylation Research, Vol. 18, pp. 119-159. Eds P. Greengard \& G. A. Robison. Raven Press, New York.

Ursely, J. \& Leymarie, P. (1979) Varying response to luteinizing hormone of two luteal cell types isolated from bovine corpus luteum. J. Endocr. 83, 303-310.

Received 1 July 1987 